EL DINAR: Jurnal Keuangan dan Perbankan Syariah

Volume 6 , No. 2, Tahun 2018

P ISSN: 2339-2797; E ISSN: 2622-0083

\title{
UPAYA MEMPERTAHANKAN LOYALITAS NASABAH PRODUK DEPOSITO DI BANK MUAMALAT INDONESIA CABANG PANGKALPINANG
}

\author{
Bapaqih Alzikri \\ Universitas Islam Negeri Sunan Kalijaga Yogyakarta \\ bapaqihalzikri@gmail.com
}

\section{Abstract}

The background of the selection of this theme is because of the data obtained from the Bank of Muamalat Indonesia, Pangkalpinang Branch on the collection of third party funds (DP3) for the performance of deposit products indicating an increase in funds collected which shows the increasing number of people who are interested in depositing funds through bank deposit products. muamalat, here the question arises in the minds of researchers how to maintain customer loyalty deposit products at the bank Muamalat Indonesia branch of Pangkalpinang. The results of the study through interviews with leaders, head funding, and marketing funding concluded that efforts to maintain customer loyalty for deposit products at Bank Muamalat Indonesia at Pangkalpinang Branch were to give special attention, provide the best service, create mutually beneficial relationships, carry out ongoing follow-up, offer attractive programs for maintain customer loyalty, and give appreciation to loyal customers. While the obstacles faced in the effort to maintain customer loyalty deposit products at the bank Muamalat pangkalpinang branch from the results of interviews with head funding and marketing funding of Muamalat Indonesia Bank, Pangkalpinang Branch are competition between banks, economic conditions, different levels of customer satisfaction, limitations funds for customer maintenance, distance between office and customer, sometimes the bank does not have an active customer telephone number, does not know the customer's residence, and customer dishonesty.

Keywords: Loyalty; Deposit Product.

\section{Abstrak}

Latar belakang pemilihan tema ini karena dari data yang diperoleh dari pihak Bank Muamalat Indonesia Cabang Pangkalpinang pada penghimpunanan dana pihak ketiga (DP3) untuk kinerja produk deposito menunjukkan adanya peningkatan dana yang berhasil dihimpun yang menunjukkan semakin banyaknya masyarakat yang tertarik untuk menyimpan danannya melalui produk deposito bank muamalat, disini muncul pertanyaan dalam pemikiran peneliti bagaimana upaya 
mempertahankan loyalitas nasabah produk deposito di bank muamalat indonesia cabang pangkalpinang. Hasil penelitian melalui wawancara kepada pimpinan, head funding, dan marketing funding disimpulkan bahwa upaya mempertahankan loyalitas nasabah produk deposito di Bank Muamalat Indonesia Cabang Pangkalpinang adalah memberikan perhatian khusus, memberikan pelayanan terbaik, ciptakan hubungan saling menguntungkan, lakukan follow up berkelanjutan, menawarkan program menarik untuk menjaga loyalitas nasabah, dan memberikan apresiasi bagi nasabah loyal. Sedangkan kendala yang dihadapi dalam upaya mempertahankan loyalitas nasabah produk deposito di bank muamalat cabang pangkalpinang dari hasil wawancara kepada pimpinan, head funding dan marketing funding Bank Muamalat Indonesia Cabang Pangkalpinang adalah Persaingan antar bank, kondisi ekonomi, perbedaan tingkat kepuasan nasabah berbeda-beda, adanya keterbatasan dana untuk maintenance nasabah, jauhnya jarak kantor dengan nasabah, terkadang pihak bank tidak mempunyai nomor telepon nasabah yang aktif, tidak mengetahui kediaman nasabah, dan ketidakjujuran nasabah.

Kata kunci: Loyalitas; Produk Deposito.

\section{PENDAHULUAN}

Masyarakat di negara maju dan berkembang sangat membutuhkan bank sebagai tempat melakukan transaksi keuangannya. Mereka menganggap bank merupakan lembaga keuangan yang aman dalam melakukan berbagai aktivitas keuangan. Di negara maju, bank menjadi lembaga yang sangat strategis dan memiliki peran penting dalam perekonomian negara. Di negara berkembang, kebutuhan masyarakat terhadap bank tidak hanya terbatas pada penyimpanan dana dan penyaluran dana saja, akan tetapi juga terhadap pelayanan jasa yang ditawarkan oleh bank (Ismail, 2011: 29).

Dalam perkembangan industri perbankan di Indonesia hingga saat ini menunjukkan semakin banyak industri perbankan yang ingin membuka bank yang sesuai dengan prinsip syariah. Ini dikarenakan perbankan syariah merupakan perbankan yang memiliki sistem yang berbeda dengan perbankan konvensional dan memiliki potensi pasar yang cukup menjanjikan di masa yang akan datang.

Bank dapat menghimpun dana masyarakat secara langsung dari nasabah. Bank merupakan lembaga yang dipercaya oleh masyarakat dalam menempatkan dananya secara aman. Di sisi lain, bank juga 
Bapaqih Alzikri: Upaya Mempertahankan Loyalitas

berperan menyalurkan dana kepada masyarakat. Bank dapat memberikan pinjaman kepada masyarakat yang membutuhkan dana. Masyarakat secara langsung mendapat pinjaman dari bank, sepanjang peminjam dapat memenuhi persyaratan yang ditetapkan oleh bank.

Dalam perkembangan industri perbankan di Indonesia hingga saat ini menunjukkan semakin banyak industri perbankan yang ingin membuka bank yang sesuai dengan prinsip syariah. Ini dikarenakan perbankan syariah merupakan perbankan yang memiliki sistem yang berbeda dengan perbankan konvensional dan memiliki potensi pasar yang cukup menjanjikan di masa yang akan datang.

Banyak tantangan dan permasalahan yang dihadapi dalam pengembangan perbankan syariah, terutama berkaitan dengan penerapan suatu sistem yang baru, yaitu sistem yang mempunyai sejumlah perbedaan prinsip dengan sistem yang dominan dan telah berkembang pesat di Indonesia (Antonio, 2011: 224).

Konsep dasar bank syariah didasarkan pada al-Qur'an dan Hadis. Semua produk dan jasa yang ditawarkan tidak boleh bertentangan dengan isi al-Qur'an dan Hadis. Bank syariah memiliki tiga fungsi utama, yaitu menghimpun dana dari masyarakat dalam bentuk titipan dan investasi, menyalurkan dana kepada masyarakat yang membutuhkan dana, dan memberikan pelayanan dalam bentuk jasa perbankan syariah.

Pada sistem dan praktiknya, bank syariah dapat berjalan dengan lancar dan berkembang pesat dengan adanya andil besar dari masyarakat sebagai nasabah penghimpun dana maupun nasabah pembiayaan. Salah satu sumber dana terpenting dari masyarakat yang dibutuhkan oleh bank adalah penghimpunan dana melalui produk tabungan, giro, dan deposito yang dikeluarkan oleh bank syariah.

Deposito adalah simpanan yang penarikannya hanya dapat dilakukan pada waktu-waktu tertentu menurut perjanjian antara penyimpan dengan bank yang bersangkutan (Kasmir, 2010: 72). Sedangkan deposito syariah adalah simpanan dana berjangka yang penarikannya hanya dapat dilakukan pada waktu tertentu berdasarkan perjanjian nasabah penyimpan dengan bank. (Sholihin, 2010: 137). Sementara dalam deposito nasabah diharapkan memberikan keloyalannya kepada bank. Loyalitas adalah sebuah kata bergaya kuno 
yang mendeskripsikan keadaan dimana seseorang yang menyerahkan seluruh jiwa dan raganya pada suatu negara, keluaraga atau temantemannya (Kotler, 2003: 111-112). Jadi apabila nasabah sudah loyal, maka bank akan sangat diuntungkan.

Data nasabah yang melakukan deposito pada periode 2011 sampai 2017 di Bank Muamalat Indonesia Cabang Pangkalpinang. Dari tahun 2011 terdapat 14 nasabah, 2012 terdapat 7 nasabah, 2013 terdapat 19 nasabah, 2014 terdapat 18 nasabah, 2015 terdapat 38 nasabah, dan tahun 2016 terdapat 105 nasabah dan jumlah keseluruhan nasabah yang masih aktif pada 4 maret 2017 terdapat 254 nasabah sebagai nasabah Bank Muamalat Indonesia Cabang Pangkalpinang (Eka, 2018).

Dari data yang diperoleh dari pihak Bank Muamalat Indonesia Cabang Pangkalpinang pada penghimpunanan dana pihak ketiga (DP3) untuk kinerja produk deposito menunjukkan adanya peningkatan dana yang berhasil dihimpun yang menunjukkan semakin banyaknya masyarakat yang tertarik untuk menyimpan danannya melalui produk Deposito Bank muamalat, hal ini ditunjukan dengan semakin banyaknya nasabah aktif Bank Muamalat yang menggunakan produk deposito sepanjang tahun 2011 sampai dengan 2017, dan produk deposito merupakan salah satu produk unggulan dan berpengaruh terhadap DP3.

Sejalan dengan kondisi di atas, penulis terdorong untuk menganalisis bagaimana upaya mempertahankan loyalitas nasabah produk deposito di Bank Muamalat Indonesia Cabang Pangkalpinang. Dengan harapan dapat membantu pihak yang berkepentingan apabila akan menggunakan jasa deposito. Sehingga penulis tertarik untuk meneliti permasalahan tersebut dengan judul "Upaya Mempertahankan Loyalitas Nasabah Produk Deposito di Bank Muamalat Indonesia Cabang Pangkalpinang".

\section{KAJIAN PUSTAKA}

Penelitian yang dilakukan oleh Ahmad Mardalis dengan penelitian yang berjudul "Meraih Loyalitas Pelanggan", yang mana peneliti mengkaji tentang faktor-faktor apa saja yang menentukan loyalitas 
pelanggan dan mengeksplorasi pertimbangan strategis penting bagi sebuah perusahaan untuk pengembangan inisiatif kesetiaan.

Adapun hasil dari Artikel ini menjelaskan faktor-faktor yang menentukan loyalitas pelanggan dan mengeksplorasi pertimbangan strategis penting bagi perusahaan yang mempertimbangkan pengembangan inisiatif kesetiaan. Ini juga membentuk pelanggan kepuasan, kualitas layanan, citra lembaga, dan penghalang peralihan dibudidayakan dengan cara itu mengarah ke kesetiaan. (Mardalis. 2005)

Sementara itu ada juga penelitian yang dilakukan oleh Nurullaila dan Andi Wijayanto yang berjudul "Analisis Faktor-Faktor Yang Mempengaruhi Loyalitas Konsumen Tupperware". Yang mana peneliti mengkaji tentang Faktor-faktor yang diduga berpengaruh terhadap loyalitas konsumen yaitu variabel kualitas, produk, harga, promosi dan desain.

Adapun Hasil penelitian menunjukkan bahwa variabel kualitas produk, harga, promosi dan desain merupakan faktor yang secara signifikan berpengaruh terhadap loyalitas konsumen. Variabel harga merupakan faktor yang paling berpengaruh terhadap loyalitas konsumen. Koefisien determinasi sebesar 0,854 menunjukkan bahwa 85,4 persen variasi loyalitas konsumen bias dijelaskan oleh keempat variabel independen yang digunakan dalam persamaan regresi. Peneltian menyarankan agar Tupperware tetap mempertahankan kualitas produk dan meningkatkan promosi agar dapat lebih dikenal masyarakat. Desain agar lebih menarik lagi agar masyarakat lebih loyal lagi terhadapproduk tersebut. (Nurullaila dan Wijayanto. 2013)

Lalu ada juga penelitian yang dilakukan oleh Sandriana Marina, Andi Darwani, dan Indra Setiawan berjudul "Pengaruh Kualitas Pelayanan terhadap Loyalitas Pelangganpada Perusahaan Penerbangan Full Service Airlines". Penelitian ini untuk mengidentifkasi pengaruh kualitas pelayanan terhadaployalitas pelanggan pada PT. Garuda Indonesia khususnya pada kantor penjualan cabang Emporium Pluit Mall Jakarta periode Maret sampai dengan April 2012.

Adapun hasilnya menunjukkan, hubungan yang kuat. Hasil uji hipotesis didapat $\mathrm{t}$ hitung $>\mathrm{t}$ table $(8.4009>1.020)$ yang berarti H0 ditolak, H1 diterima. Artinya ada hubungan signifkan antara variabel 
kualitas (X) dan variabel loyalitas pelanggan (Y). ( Marina, Darwani, dan Setiawan. 2014)

Dan ada juga penelitian yang dilakukan oleh Husein Umar yang berjudul "Faktor-faktor yang Memengaruhi Loyalitas Pelanggan pada Penerbangan Low Cost Carrier" penelitian ini mengkaji tentang Peristiwa yang terjadi pada lingkungan eksternal industri penerbangan berbiaya rendah (low cost carrier), seperti perubahan peraturan dan kebijakan pemerintah serta perkembangan kondisi ekonomi dunia telah berdampak pada perkembangan industry penerbangan ini.

Adapun hasilnya menunjukkan Fakta empiris menyatakan bahwa perlu upaya ekstra untuk mempertahankan dan meningkatkan loyalitas konsumen. Penelitian ini dilakukan pada penerbangan LCC domestik terjadwal. Data dianalisis menggunakan LISREL 8.8, hasil analisis CFA dan Struktural Model Fit menyatakan model penelitian baik. (Umar, 2014). Sedangkan yang menjadi fokus penelitian peneliti adalah upaya mempertahankan loyalitas nasabah produk deposito di Bank Muamalat Indonesia Cabang Pangkalpinang. Dalam hal ini, berarti penelitian ini mengembangkan penelitian sebelumnya.

\section{METODE PENELITIAN}

Metode penelitian yang digunakan pada penelitian ini adalah deskriptif kualitatif yaitu suatu penelitian yang ditujukan untuk mendeskripsikan dan menganalisis fenomena, peristiwa, aktivitas sosial, sikap, kepercayaan, persepsi, pemikiran orang secara individual maupun kelompok (Sugiyono, 2006: 10). Teknik pengumpulan data pada penelitian ini melalui observasi, wawancara dan dokumentasi. Dengan menggunakan metode deskriptif kualitatif peneliti menelaah upaya mempertahankan loyalitas nasabah tabungan deposito berdasarkan akad mudharabah muthlaqah di Bank Muamalat Indonesia Cabang Pangkalpinang.

\section{PAPARAN HASIL PENELITIAN DAN PEMBAHASAN}

Peneliti membahas suatu kajian terhadap hasil penelitian yang telah dilakukan dengan analisa secara deskriptif, yaitu mengkaji tentang upaya mempertahankan loyalitas nasabah produk deposito di Bank 
Bapaqih Alzikri: Upaya Mempertahankan Loyalitas

Muamalat Indonesia Cabang Pangkalpinang serta kendala yang dihadapi dalam upaya mempertahankan loyalitas nasabah produk deposito di Bank Muamalat Indpnesia Cabang Pangkalpinang.

Hasil penelitian ini merupakan rangkuman dari hasil wawancara dengan pihak Bank Muamalat Indonesia Cabang Pangkalpinang. Wawancara ini dilakukan dengan pimpinan Bank Muamalat Indonesia Cabang pangkalpinang, Head Funding dan dengan Marketing Funding Bank Muamalat Indonesia Cabang Pangkalpinang.

\section{Upaya Mempertahankan Loyalitas Nasabah Produk Deposito di Bank Muamalat Indonesia Cabang Pangkalpinang}

Loyalitas merupakan kondisi psikologis yang berkaitan dengan sikap terhadap produk, nasabah akan membentuk keyakinan menetapkan suka dan tidak suka terhadap produk yang diciptakan suatu perusahaan. Dimensi sikap merupakan niat dan preferensi nasabah untuk jasa atau produk tertentu. Niat untuk membeli atau niat untuk merekomendasikan dan preferensi pada suatu perusahaan merupakan faktor penting dalam menentukan bisnis di masa yang akan datang.

Semakin besar niat nasabah untuk menggunakan produk secara berulang dan niat untuk merekomendasikan suatu perusahaan memberikan suatu indikasi bahwa perusahaan tersebut mempunyai bisnis yang cerah di masa depan. Sehingga dimensi sikap ini merupakan indikasi yang baik untuk pengukuran loyalitas nasabah. Dengan kata lain dimensi ini akan memberikan indikasi apakah nasabah akan tetap membeli lagi atau pindah pada perusahaan lain.

Menurut wawancara dengan bapak Yoven Harnavi selaku pimpinan Bank Muamalat Indonesia Cabang Pangkalapinang mengatakan loyalitas sebagai berikut :( Haerudin. 2018).

"Loyalitas merupakan kesetiaan, kenyamanan, serta kepuasan nasabah atas layanan bank. Sebagai pimpinan bank, ada bebrapa hal yang saya tugaskan kepada teman-teman marketing dalam mempertahankan loyalitas nasabah seperti mengadakan kunjungan ke rumah-rumah nasabah, memberikan kartu ucapan selamat pada perayaan hari-hari besar, serta mengadakan acara hajatan yang diadakan nasabah apabila kita diundang".

Loyalitas nasabah akan menjadi kunci sukses, tidak hanya dalam jangka pendek tetapi keunggulan bersaing secara berkelanjutan. Hal ini karena 
Bapaqih Alzikri: Upaya Mempertahankan Loyalitas

loyalitas nasabah memiliki nilai strategis bagi perusahaan, kesuksesan suatu perusahaan tidak terlepas dari ikatan loyalitas yang kuat dari nasabahnya.

Mengingat persaingan dikalangan dunia perbankan yang semakin ketat, kemampuan dalam mempertahankan loyalitas nasabah secara berkesinambungan menjadi kunci keunggulan bersaing suatu perbankan. Pada umumnya setiap perbankan menginginkan agar nasabah yang ada dapat dipertahankan selamanya. Namun hal ini bukanlah suatu tugas yang mudah mengingat perubahan-perubahan pada nasabah yang dapat terjadi setiap saat, baik perubahan pada diri nasabah seperti keinginan maupun aspek-aspek psikologis serta perubahan kondisi lingkungan yang mempengaruhi aspek-aspek psikologis sosial dan cultural pelanggan.

Upaya Mempertahankan Loyalitas Nasabah: Pimpinan Bank Muamalat Indonesia Cabang Pangkalpinang

Berdasarkan wawancara dengan pimpinan Bank Muamalat Indonesia Cabang Pangkalpinang yaitu bapak Yoven Harnavi mengatakan bahwa agar nasabah tidak berpaling ke bank lain maka bank perlu mempertahankan loyalitas nasabah dengan cara seperti berikut:(Haerudin. 2018)

1. Memberikan perhatian khusus

Sebagian besar pelaku pasar hanya fokus terhadap penawaran yang akan mereka sampaikan, tanpa memperhatikan keinginan nasabah. Kesalahan inilah yang sering membuat para nasabah melakukan penolakan secara langsung terhadap para marketing, sebab mereka menganggap para marketing hanya akan berpromosi menawarkan sebuah produk. Karenanya untuk menciptakan kepuasan nasabah, berikan perhatian khusus kepada para nasabah baik sebelum terjadi transaksi maupun pasca transaksi. Misalnya saja dengan membagikan katalog menarik untuk memancing minat nasabah, serta memberikan garansi khusus pada produk unggulan yang anda pasarkan.

Salah satu cara yang diakukan untuk mempertahankan loyalitas nasabah adalah dengan cara memberikan perhatian kepada nasabah agar nasabah tetap merasa nyaman untuk 
menempatkan dan mempertahankan dananya di Bank Muamalat Indonesia Cabang Pangkalpinang. Ada beberapa cara yang dilakukan oleh Bank Muamalat Indonesia Cabang Pangkalpinang dalam memberikan perhatian khusus kepada nasabah. Salah satu cara yang dilakukan adalah ketika nasabah berulang tahun ucapkan selamat ulang tahun dan memberikan kue ataupun hadiah ulang tahun, memberikan bingkisan menjelang lebaran. Hal ini biasanya dilakukan oleh marketing funding Bank Muamalat Indonesia Cabang Pangkalpinang.

2. Menciptakan hubungan yang saling menguntungkan

Dalam memasarkan sebuah produk, tak jarang para pelaku pasar atau marketing lebih mendominasi komunikasi yang terbangun. Mereka memposisikan para nasabah sebagai pendengar, dan pemasar sebagai narasumber utamanya. Strategi pemasaran seperti ini tentunya terbilang kuno, sebab sekarang ini para konsumen sudah mulai cerdas dan bisa menentukan produkproduk unggulan yang bisa memenuhi kebutuhan mereka. Oleh sebab itu, pastikan hubungan yang terbangun antara nasabah dan pelaku pasar bisa seimbang dan saling menguntungkan.

Selain menawarkan beragam produk dengan berbagai keunggulannya yang dapat menarik minat nasabah di Bank Muamalat Indonesia Cabang Pangkalpinang. Pihak Bank tentu berusaha untuk menjaga loyalitas nasabah. Selain memberikan perhatian khusus seperti yang dijelaskan diatas Bank Muamalat Indonesia Cabang Pangkalpinang biasanya menawarkan produk lain yang lebih unggul. Dimana produk yang ditawarkan tersebut tentu bisa memberikan keuntungan bagi para nasabah dan sekaligus bisa memberikan keuntungan pula bagi pihak bank.

3. Melakukan follow up berkelanjutan.

Follow up adalah tindak lanjut kita terhadap para calon pembeli produk yang sudah mendapatkan informasi mengenai bisnis atau produk yang dijual. Untuk mempertahankan loyalitas pelanggan, ada baiknya Anda mencatat semua nasabah yang pernah membeli produk anda dan mencoba melakukan follow up ulang pasca pembelian pertama. Meskipun cara ini sangatlah 
mudah, namun sampai hari ini belum semua pelaku usaha melakukannya. Biasanya mereka kurang peduli dengan prospek yang sudah dimiliki, dan cenderung mencari sasaran (nasabah baru) dibandingkan harus mem-follow up ulang nasabah-nasabah yang pernah melakukan pembelian di perusahaan mereka.

Sedangkan di Bank Muamalat Indonesia Cabang Pangkalpinang follow up itu sendiri dilakukan oleh tim marketing funding dengan caranya yaitu bersilahturahmi, janji ketemu, menelpon dan intinya ada tidak lanjuti dari pihak Bank Muamalat Indonesia terhadap nasabah tersebut.

4. Menawarkan program menarik untuk menjaga loyalitas nasabah

Untuk menjaga loyalitas para nasabah Mulailah dengan menawarkan program premium untuk menjaga loyalitas para nasabah. Dapat juga dengan menawarkan produk khusus yang akan memberikan banyak keuntungan bagi nasabah setia anda, misalnya saja dengan memberikan bonus tertentu bagi para nasabah yang melakukan peningkatan dana.

Selain itu kita sebagai mitra nasabah harus bisa menganalisa setiap kebutuhan-kebutuhan nasabah dan menawarkan produk yang sesuai dengan kebutuhan nasabah. Apabila nasabah menyukai produk yang kita tawarkan sehingga akan menambah loyalitas nasabah kepada Bank Muamalat Indonesia Cabang Pangkalpinang. Program-program menarik tersebut itu adalah:

a) Program Tabungan Haji Berkah, produk ini memiliki penawaran kepada nasabah yang menggunakannya berkesempatan mendapatkan undian umroh setiap bulannya. Caranya cukup dengan setoran awal Rp. 5.000.000,00 (lima juta rupiah) dan setiap bulannya nasabah wajib menabung Rp. 100.000,00 (seratus ribu rupiah), karena setiap Rp. 1.000.000,00 (satu juta rupiah) itu mendapatkan 1 poin dan poin yang paling banyak terkumpul itulah pemenangnnya.

b) Tabungan Prima Berhadiah, setiap nasabah yang membuka tabungan prima minimal Rp. 25.000.000,00 (dua puluh lima juta rupiah) dengan jangka waktu tertentu akan 
mendapatkan hadiah langsung dari Bank Muamalat Indonesia.

c) Deposito Berkah, merupakan pemberian spesial nisbah (bagi hasil) yang lebih tinggi untuk nasabah dengan nominal tertentu.

d) Sponsor, misalnya nasabah ada kegiatan tertentu dan pihak Bank Muamalat Indonesia Cabang Pangkalpinang ikut membatu dalam hal pendanaan atau pun lainnya.

e) Memberikan apresiasi bagi nasabah loyal, di Bank Muamalat Indonesia itu sendiri memberikan apresiasi kepada nasabah ada yang berbentuk barang yaitu berupa souvenir, dan untuk nasabah yang nominal tabungannya lebih tinggi apresiasi yang kami berikan adalah ucapan selamat ulang tahun pada hari ulang tahun dengan membawa sebuah kue ulang tahun, dan dalam suatu kegiatan misalnya acara/kegiatan sosial seperti qurban atau belanja anak yatim disini kami mengajak nasabah untuk berpartisipasi dalam kegiatan tersebut.

Upaya Mempertahankan Loyalitas Nasabah: Marketing Funding Bank Muamalat Indonesia Cabang Pangkalpinang

Berikut ini dijelaskan secara singkat mengenai upaya mempertahankan loyalitas nasabah produk deposito di Bank Muamalat Indonesia Cabang Pangkapinang menurut Dedy Sunandar selaku marketing funding, yaitu: (Sunandar, 2018)

1. Memberikan pelayanan terbaik

Pelayanan adalah strategi yang cukup ampuh dalam rangka mempertahankan loyalitas nasabah Bank Muamalat Indonesia Cabang Pangkalpinang, pelayanan merupakan salah satu usaha yang dilakukan perusahaan atau jasa untuk melayanai nasabah dengan sebaik-baiknya, sehingga dapat memberikan kepuasan pada nasabah dan memenuhi harapan dan kebutuhan nasabah.

Dalam memberikan pelayanan terbaik pihak Bank Muamalat Indonesia berusaha semaksimal mungkin untuk melayani nasabah yang melakukan transaksi atau yang ingin menyampaikan keluhannya. 
2. Sering bersilaturrahmi terkait produk dan layanan yang ada

Dalam hal ini pihak Bank Muamalat Indonesia Cabang Pangkalpinang sering bersilaturrahmi kerumah-rumah nasabah khususnya nasabah deposito.

3. Menginformasikan produk dan layanan terbaru

Pihak Bank Muamalat Indonesia Cabang Pangkalpinang biasanya menginformasikan produk dan layanan terbaru kepada nasabah melalui telpon, via sms dan langsung mendatangi kediaman nasabah tersebut.

4. Memberikan fasilitas cash pick up untuk nasabah yang penyetoran yang besarnya minimal 25 juta

Fasilitas pelayanan untuk nasabah yang tidak dapat datang langsung ke bank untuk keperluan transaksi minimal RP. 25.000.000,00 (dua puluh lima juta rupiah) maka pihak Bank Muamalat Indonesia Cabang Pangkalpinang khususnya tim marketing dapat mendatangi langsung kediaman nasabah tersebut.

5. Memberikan gift atau souvenir kepada nasabah

Souvenir diberikan kepada nasabah yang menggunakan produk tertentu dan melakukan transaksi dengan jumlah tertentu.

Upaya Mempertahankan Loyalitas Nasabah: Head Funding Bank Muamalat Indonesia Cabang Pangkalpinang

Sedangkan menurut Dalila selaku head funding tidak jauh berbeda dari apa yang disampaikan oleh bapak Dedy Sunandar selaku marketing funding yaitu sering silaturrrahmi, selalu menginformasikan produk terbaru, memberikan souvenir kepada nasabah serta memberikan perhatian khusus dengan menelpon nasabah walau hanya menaanyakan kabar (Dalila, 2018).

\section{Kendala yang Dihadapi Dalam Upaya Mempertahankan Loyalitas Nasabah Produk Deposito di Bank Muamalat Cabang Pangkalpinang}

Situasi persaingan dalam dunia perbankan sekarang semakin keras, dan perusahaan memiliki kemampuan untuk meningkatkan loyalitas nasabah secara berkesinambungan menjadi kunci keunggulan bersaing perusahaan. Perusahaan pada umumnya menginginkan bahwa 
nasabah yang ada dapat dipertahankan selamanya. Ini bukan tugas yang mudah mengingat perubahan-perubahan dapat terjadi setiap saat, baik perubahan pada diri nasabah seperti keinginan maupun aspek-aspek psikologis serta perubahan kondisi lingkungan yang mempengaruhi aspek-aspek psikologis sosial dan cultural pelanggan.

Dalam perkembangan industri perbankan di Indonesia hingga saat ini menunjukkan semakin banyak industri perbankan yang ingin membuka bank yang sesuai dengan prinsip syariah. Ini dikarenakan perbankan syariah merupakan perbankan yang memiliki sistem yang berbeda dengan perbankan konvensional dan memiliki potensi pasar yang cukup menjanjikan di masa yang akan datang.

Banyak tantangan dan permasalahan yang dihadapi dalam pengembangan perbankan syariah, terutama berkaitan dengan penerapan suatu sistem yang baru, yaitu sistem yang mempunyai sejumlah perbedaan prinsip dengan sistem yang dominan dan telah berkembang pesat di Indonesia. Begitu halnya dengan Bank Muamalat Indonesia Cabang Pangkalpinang. Salah satu produk yang menjadi unggulan di Bank ini adalah Produk Deposito.

Kendala yang dihadapi: Pimpinan Bank Muamalat Indonesia Cabang Pangkalpinang

Dalam upaya mempertahankan loyalitas nasabah, pihak bank juga mengalami beberapa kendala, seperti yang dipaparkan oleh pimpinan Bank Maumalat Cabang Pangkalpinang beliau menyebutkan ada beberapa kendala yang kami hadapi dalam upaya mempertahankan loyalitas nasabah khususnya nasabah deposito. Adapun kendala tersebut secara umum yaitu persaingan antar bank, kondisi ekonomi, serta perbedaan tingkat kepuasan nasabah berbeda-beda (Haerudin, 2018). Uraian dari kendala-kendala diatas adalah sebagai berikut:

1. Persaingan antar bank

Persaingan antar bank saat ini semakin ketat. Saat ini, tumbuh dan berkembangnya bank tidak hanya ditandai dengan banyaknya kantor cabang yang dibuka tetapi dapat dilihat dari munculnya produk-produk baru dengan segala macam atribut yang dimiliki oleh setiap bank seperti memberikan bagi hasil yang 
tinggi, jaminan kredit, berbagai hadiah, fasilitas on line, phone banking, anjungan tunai mandiri (ATM), serta fasilitas lainnya.

Dalam Bank Muamalat Indonesia Cabang Pangkalpinang untuk mengatasi persaingan antar bank yaitu dengan menggiatkan kembali tim marketing untuk memasarkan produk secara optimal (menggencarkan pemasaran).

2. Kondisi ekonomi

Dilihat dari pertumbuhan ekonomi di Bangka Belitung saat ini, masyarakat banyak yang beralih pekerjaan dari TI (Tambang Inkonvensional) ke Pertanian terutama perkebunan lada ataupun sawit, Dikarnakan banyaknya larangan atau aturan dari pemerintah daerah untuk mengoprasikan TI (Tambang Inkonvensional).

Bank Muamalat Indonesia Cabang Pangkalpinang melihat itu adalah sebagai faktor eksternal, dan untuk mengantisipasi dampak hal tersebul misalnya nasabah yang ingin mencairkan dananya $100 \%$, tetapi dari pihak bank menyarankan untuk mencairkan secara bertahap-tahap.

3. Perbedaan tingkat kepuasan nasabah berbeda-beda

Memuaskan kebutuhan nasabah adalah keinginan setiap perusahaan. Selain faktor penting bagi kelangsungan hidup perusahaan, memuaskan kebutuhan nasabah dapat meningkatkan keunggulan dalam persaingan. Nasabah yang puas terhadap produk dan jasa pelayanan cenderung untuk membeli kembali produk dan menggunakan kembali jasa pada saat kebutuhan yang sama muncul kembali dikemudian hari. Hal ini berarti kepuasan merupakan faktor kunci bagi nasabah dalam melakukan pembelian ulang yang merupakan porsi terbesar dari volume penjualan perusahaan.

Bagi Bank Muamalat Indonesia Cabang Pangkalpinang kepuasan nasabah adalah hal yang utama, maka dari itu pihak bank berusaha membuat nasabah merasa puas dengan cara: 
4. Meningkatkan kualitas produk

Nasabah akan merasa puas bila hasil evaluasi mereka menunjukkan bahwa produk yang mereka gunakan berkualitas.

5. Meningkatkan kualitas pelayanan

Nasabah akan merasa puas bila mereka mendapatkan pelayanan yang baik atau yang sesuai dengan yang diharapkan.

Kendala yang dihadapi: Marketing Funding Muamalat Indonesia Cabang Pangkalpinang

Seperti yang dipaparkan oleh Bapak Dedy Sunandar selaku marketing funding menyampaikan beberapa kendala, beliau menyebutkan ada beberapa kendala yang kami hadapi dalam upaya mempertahankan loyalitas nasabah khususnya nasabah deposito adalah adanya keterbatasan dana untuk maintenance nasabah, jauhnya jarak kantor dengan nasabah, terkadang pihak bank tidak mempunyai nomor telepon nasabah yang aktif, dan tidak mengetahui kediaman nasabah tersebut (Sunandar, 2018). Uraian dari kendala-kendala tersebut adalah sebagai berikut:

1. Adanya keterbatasan dana untuk maintenance nasabah.

Bank Muamalat Indonesia Cabang Pangkalpinang disini tidak mempunyai cukup dana untuk maintenance keseluruahan nasabah dikarnakan banyaknya jumlah nasabah deposito tersebut, sehingga pelayanan kami dalam maintenance nasabah tersebut kurang maksimal. Upaya kami dalam meminimalisirkan masalah tersebut adalah dengan memaksimalkan penggunaan dana yang ada sebaik mungkin.

2. Jauhnya jarak kantor dengan nasabah

Ruang lingkup kegiatan pemasaran produk yang dilakukan pihak marketing Bank Muamalat Indonesia Cabang Pangkalpinang biasanya tidak selalu disekitaran lokasi kantor bank, namun ada nasabah yang sangat jauh dari kantor sehinggga tim marketing tidak dapat memaksimalkal pelayanannya kepada nasabah yang rumahnya jauh tersebut. Cara yang dilakukan oleh pihak Bank Muamalat Indonesia Cabang Pangkalpinang adalah 
dengan cara menghubungi nasabah tersebut melalui telpon, handphone dan media sosial agar nasabah merasa diperhatikan.

3. Terkadang pihak bank tidak mempunyai nomor telepon nasabah yang aktif

Masalah ini terjadi biasanya dikarnakan nasabah mengganti nomor telponnya tanpa menkonfirmasi terlebih dahulu kepada pihak bank sehingga pihak bank kesulitan untuk menghubungi nasabah tersebut. Adapun untuk mengatasi masalah tersebut, pihak bank mendatangi kediaman nasabah yang bersangkutan dan menanyakan langsung nomor telpon yang aktif sekalian bersilaturahmi.

4. tidak mengetahui kediaman nasabah.

Selain masalah-masalah diatas terdapat pula masalah yang sering terjadi pada nasabah terutama nasabah deposito adalah pihak Bank Muamalat Indonesia Cabang Pangkalpinang tidak mengetahui alamat pasti nasabah tersebut dikarnakan nasabah berpindah alamat rumah atau penulisan alamat kurang lengkap saat pengisian formulir awal transaksi. Untuk mengatasi masalah tersebut pihak Bank Muamalat Indonesia Cabang Pangkalpinang biasanya mendatangi langsung desa atau kota tempat tinggal nasabah tersebut dengan menanyakan kepada masyarakat sekitarnya.

Kendala yang dihadapi: Head Funding Muamalat Indonesia Cabang Pangkalpinang

Wawancara yang dilakukan peneliti terhadap ibu Dalila selaku head funding terdapat beberapa kendala tersebut adalah sebagai berikut: (Dalila. 2018)

1. Adanya penawaran dari bank lain

Adanya persaingan antar bank dalam produk yang sama, biasanya nasabah memilih produk yang lebih unggul atau lebih menguntungkan nasabah. Cara mengatasi masalah tersebut adalah dengan memberikan layanan perbankan lebih maksimal lagi, menawarkan produk yang lebih berfariatif yang sesuai dengan kebutuhan nasabah. 
2. Kurangnya perhatian

Dalam hal menjaga loyalitas nasabah salah satu yang menjadi kendala bagi pihak bank adalah kurangnya perhatian dikarnakan jumlah nasabah deposito yang banyak sehingga belum maksimalnya perhatian dari pihak bank untuk seluruh nasabah terutama nasabah deposito.

Dan cara mengatasi masalah tersebut dari pihak Bank Muamalat Indonesia Cabang Pangkalpinang yaitu jika pihak bank tidak bisa bertemu langsung kepada nasabah, dapat juga melalui telpon atau via sms sekedar mengucapkan selamat ulang tahun misalnya.

\section{Ketidakjujuran nasabah}

Macam-macam kriteria nasabah yang ada di Bank Muamalat Indonesia Cabang Pangkalpinang terkadang ada yang sengaja berbohong hanya untuk alasan mencairkan dananya, contohnya, alasan nasabah mecairkan dana tersebut untuk keperluan darurat padahal setelah di cari informasi yang lebih dari pihak bank ternyata dana tersebut digunakan untuk pindah ke bank lain.

Cara mengatasi masalah tersebut adalah dengan menggali informasi yang lebih dalam terhadap penggunaan dana yang ingin dicairkan dan memberikan beberapa saran dan solusi bersama kepada nasabah yang bersangkutan agar tidak mencairkan dananya.

Dari hasil wawancara yang peneliti lakukan terhadap pimpinan, head funding, dan marketing funding Bank Muamalat Indonesia Cabang Pangkalpinang maka dapat peneliti simpulkan bahwa, dalam pertanyaan upaya mempertahankan loyalitas nasabah produk deposito di bank muamalat indonesia cabang pangkalpinang dan apa kendala yang dihadapi dalam upaya mempertahankan loyalitas nasabah produk deposito di bank muamalat cabang pangkalpinang.

Adapun hasil wawancara kepada pimpinan, head funding dan marketing funding tentang upaya mempertahankan loyalitas nasabah produk deposito di bank muamalat indonesia cabang pangkalpinang adalah Memberikan perhatian khusus, memberikan pelayanan terbaik, 
ciptakan hubungan saling menguntungkan, lakukan follow up berkelanjutan, menawarkan program menarik untuk menjaga loyalitas nasabah, dan memberikan apresiasi bagi nasabah loyal.

Sedangkan kendala yang dihadapi dalam upaya mempertahankan loyalitas nasabah produk deposito di bank muamalat cabang pangkalpinang dari hasil wawancara kepada pimpinan, head funding dan marketing funding Bank Muamalat Indonesia Cabang Pangkalpinang adalah Persaingan antar bank, kondisi ekonomi, perbedaan tingkat kepuasan nasabah berbeda-beda, adanya keterbatasan dana untuk maintenance nasabah, jauhnya jarak kantor dengan nasabah, terkadang pihak bank tidak mempunyai nomor telepon nasabah yang aktif, tidak mengetahui kediaman nasabah, dan ketidakjujuran nasabah.

\section{KESIMPULAN}

Berdasarkan hasil penelitian yang dilakukan peneliti di Bank Muamalat Indonesia Cabang Pangkalpinang, maka dapat disimpulkan bahwa:

1. Upaya mempertahankan loyalitas nasabah produk deposito di bank muamalat indonesia cabang pangkalpinang sebagai berikut: 1) Memberikan perhatian khusus; 2) Memberikan pelayanan terbaik; 3) Menciptakan hubungan saling menguntungkan; 4) Melakukan follow up berkelanjutan; 5) Menawarkan program menarik untuk menjaga loyalitas nasabah; dan 6) Memberikan apresiasi bagi nasabah loyal.

2. Kendala Yang Dihadapi Dalam Upaya Mempertahankan Loyalitas Nasabah Produk Deposito di bank Muamalat Cabang Pangkalpinang adalah sebagai berikut: 1) Persaingan antar bank; 2) Kondisi ekonomi; 3) Perbedaan tingkat kepuasan nasabah berbeda-beda; 4) Adanya keterbatasan dana untuk maintenance nasabah; 5) Upaya Bank Muamalat Indonesia Cabang Pangkalpinang dalam meminimalisirkan masalah diatas adalah dengan memaksimalkan penggunaan dana yang ada sebaik mungkin; 6) Jauhnya jarak kantor dengan nasabah; 7) Terkadang pihak bank tidak mempunyai nomor telepon nasabah yang aktif; 
8) Tidak mengetahui kediaman nasabah; dan 9) Ketidakjujuran nasabah.

\section{SARAN}

Dari pembahasan di atas, peneliti memberikan saran sebagai berikut:

1. Pihak Bank Muamalat Indonesia Cabang Pangkalpinang harus senantiasa menjaga silaturrahmi dengan pihak nasabah agar loyalitas nasabah terhadap bank tetap terjaga.

2. Agar perkembangan jumlah nasabah deposito tetap meningkat, pihak bank harus senantiasa mempromosikan produk-produk yang sesuai dengan kebutuhan nasabah serta memberikan pelayanan yang optimal demi mewujudkan kepuasan nasabah.

3. Kendala-kendala yang dihadapi dalam upaya mempertahankan loyalitas nasabah adalah sebuah tantangan bagi setiap perbankan. Oleh karena itu, pihak Bank Muamalat Indonesia Cabang Pangkalpinang harus menciptakan strategi-strategi baru demi mempertahankan loyalitas nasabah terhadap bank.

\section{DAFTAR PUSTAKA}

Ahmad, I. S., 2010. Pedoman Umum Lembaga Keuangan Syariah. Jakarta: PT Gramedia Pustaka Utama.

Ahmad, M. 2005. Meraih Loyalitas Pelanggan. Jurnal BENEFIT, Vol. 9, No. 2.

Bustami. 2008. Metodologi Penelitian dan Pendidikan, Pendekatan Kualitatif dan Kuantitatif, Bandung, Raja Grafindo Perseda.

Dalila, Head Funding, Bank Muamalat Indonesia Cabang Pangkalpinang, wawancara, 4 juni 2018.

Dedy, S. Marketing funding, Bank Muamalat Indonesia Cabang Pangkalpinang, Wawancara, 4 juni 2018.

Eka, (Customer Service), Bank Muamalat Indonesia Cabang Pangkalpinang, Wawancara, 4 juni 2018.

Husein, U. 2014. Faktor-faktor yang Memengaruhi Loyalitas Pelanggan pada Penerbangan Low Cost Carrier. Jurnal Manajemen Transportasi \& Logistik (JMTransLog) - Vol. 01 No. 02.

Ismail. 2011. Perbankan Syariah. Jakarta: Kencana.

Kasmir. 2010. Manajemen Perbankan. Jakarta: Rajawali Pers. 
Bapaqih Alzikri: Upaya Mempertahankan Loyalitas

Mohamad, H. Pimpinan Bank Muamalat Indonesia Cabang Pangkalpinang, wawanacara, 4 Juni 2018.

Muhammad, S. A., 2011. Bank Syariah: Dari Teori ke Praktik. Jakarta: Gema Insani.

Nurullaili dan Andi, W., 2013. Analisis Faktor-Faktor Yang Memengaruhi Loyalitas Konsumen Tupperware. Jurnal Administrasi Bisnis, Volume 2, No 1.

Philip, K. 2003. Marketing Insight From A to Z. Jakarta: Erlangga .

Sandriana, M, Andi, D, dan Indra, S., 2014. Pengaruh Kualitas Pelayanan terhadap Loyalitas Pelanggan pada Perusahaan Penerbangan Full Service Airlines. Jurnal Manajemen Transportasi \& Logistik (JMTransLog), Vol. 01 No. 02.

Sugiyono. 2006. Metode Penelitian Kualitatif dan Kuantitatif. Bandung: Alfabeta. 